\title{
Die medereisiger wat sin aan die reis gee
}

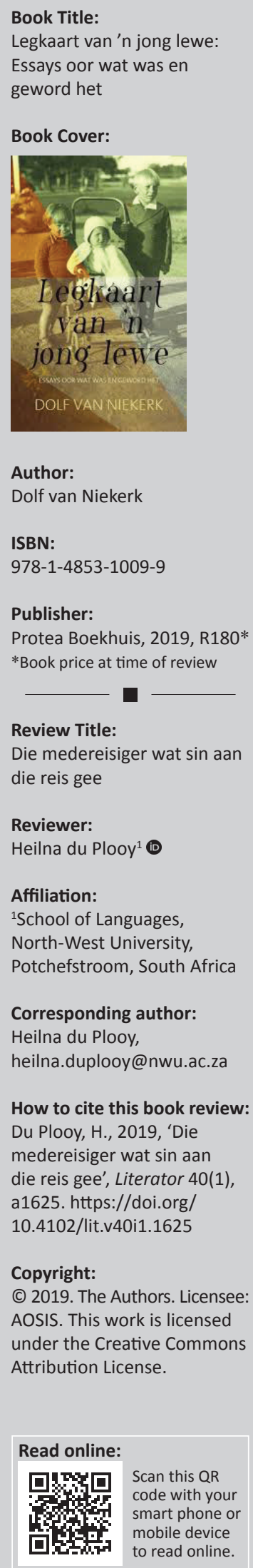

Dolf van Niekerk is een van die mees deurwinterde skrywers in Afrikaans. Trouens, hy was deel van die Sestigerbeweging en nou, ongeveer vyftig jaar later op negentigjarige ouderdom, skryf hy steeds. Die Afrikaanse letterkunde is ryk aan gerypte skrywers: T.T. Cloete, Elsa Joubert en Elisabeth Eybers van die ouer garde, asook ander Sestigers soos Breyten Breytenbach en Abraham H. de Vries. Dolf van Niekerk is een van hierdie groep beleë skrywers wat steeds werk van gehalte produseer. Hy het in verskillende genres gepubliseer, onder meer jeugverhale, poësie, romans en radiodramas. In 2017 verskyn Kroniek van turf, 'n prosateks wat op 'n manier beskryf kan word as 'n 'kort begrip' van die Suid-Afrikaanse geskiedenis deurdat hy in die uitbeelding van die karakters se lewensloop bepaalde bykans argetipiese elemente van die Suid-Afrikaanse geskiedenis aan die orde stel.

Legkaart van 'n jong lewe, sy jongste publikasie, bevat 'n reeks van 48 essays of verhalende sketse waarin hy besin oor sy eie jeug. Ek noem die stukke spesifiek 'n reeks omdat daar baie duidelik 'n opbou en samehang tussen die onderdele bestaan. Die essayistiese sketse of verhalende essays dek die verloop van 'n hele jeug, vanaf ongeveer die vyfde lewensjaar van die skrywer tot net voor sy een-en-twintigste verjaarsdag. Elke essay beskryf 'n belangrike en selfs bepalende moment of gebeurtenis in die skrywer se lewe, maar hierdie gebeurtenisse dra meer gewig as net 'n persoonlike herinnering. Die vertelling bly steek nie in die blote gegewe nie, maar is telkens 'n subtiele besinning oor die insident of omstandighede in verhouding tot die deurlopende vraagstuk waarmee die skrywer gemoeid is, naamlik die vraag oor wat die menslike bewussyn eintlik is of sou kon wees. In die lig van hierdie vraagstelling kry jeugherinneringe 'n bykomende dimensie, in die skrywer se eie woorde in die inleiding: "die "iets" van my kinderbelewenis is nie enkelvoudig, vaspenbaar, tasbaar of selfs denkbaar nie' (bl. 13). Die skrywer onthou'n geleentheid toe hy omtrent vyf was en saam met sy pa in die veld was, toe hy bewus geword het daarvan dat 'wat in my bewussyn en in die wêreld om my is onafskeidbaar is' (bl. 9). En deur die res van die inleiding en in die essays self loop daar ' $n$ lyn wat gemoeid is met die bewussyn soos die skrywer vertel hoe hy met filosowe en skrywers se werk kennis gemaak het, van die klassieke af deur die eeue tot by Dostojewski en Nietzsche en N.P. van Wyk Louw. Deur hierdie soektogte vind sy speurende gees dan sy passie vir kennis en insig wat in sy eie skryfwerk gestalte vind.

Die vertellings openbaar die nadenke oor die bestaan van een mens, maar gee ook 'n beeld van wie en wat hierdie mens is. Sy belewenisse is bepaal deur sy eie onselfbewuste en onwillekeurige psigiese ingesteldheid teenoor homself en sy omwêreld, en terwyl spesifieke gebeure hom gevorm het, toon sy reaksies op die gebeure ook die kernaspekte van sy latere geestelike ontwikkeling aan.

As mens die stukke as sketse beskou, gee dit 'n beeld van 'n verbygegane lewenstyl: die kleindorpse wêreld, waar seuns help as petroljoggies, om pos af te lewer, om die dokter te gaan roep, om aan huis van ouer mense te gaan slaap om hulle op te pas; 'n lewe met min geld en harde werk; 'n wêreld waar kos gekweek word in 'n groentetuin en waar iets soos 'n pak klere skaars is en geleen of geërf word; 'n gemeenskap waarin almal mekaar ken en mekaar help. Dit was ook die tyd van kleindorpse konserte en reisende toneelgeselskappe, 'n tyd toe studente per fiets van Bloemfontein na Edenburg moes ry omdat daar nie geld vir 'n treinkaartjie was nie, en daar noukeurig gespaar moes word om 'n boek vir 'n paar pennies te koop. In hierdie opsig word 'n hele stuk Suid-Afrikaanse plattelandse geskiedenis en kultuur in die sketse en verhale vasgevang, 'n onskuldiger wêreld en 'n byna naïewe tyd, maar tog 'n tydperk van ryke menslikheid waarin al die bestanddele van 'n latere lewe en die volgende fases van die geskiedenis reeds aanwesig is.

Belangrike sake in die jeuglewe van Van Niekerk is die feit dat sy moeder oorlede is ' $n$ maand ná sy geboorte en dat daar by hom 'n soort onderdrukte skuldgevoel is dat sy bestaan dalk bygedra het tot sy moeder se dood. Verder is daar sy pa se siekte, 'n ernstige longkwaal wat sy lewensgehalte ondermyn het en hierdie twee feite keer telkens terug in sy werk. Van die sketse is oorgeneem uit vroeëre verhaalbundels, maar hier voeg alles naatloos saam, waaruit mens kan sien dat Van Niekerk se oeuvre deurlopende lyne vertoon en so gebind is. In hierdie sketse plaas die skrywer egter groot klem op sy ontdekking van die wêrelde van kennis en insig via die filosofie en die letterkunde, en natuurlik van die wêreld van musiek. 
Daar is klein insidente wat beskryf word, soos hoe hy sy sussie se selluloïedpop se neus teen die kersvlam laat smelt het, maar ook belangriker lewensbepalende ervarings soos hoe hy elke keer die dokter moes gaan roep in die nag toe 'n jonger sustertjie van hom sterwend was. Die skrywer onthou hoe hy as kleindorpse kind met 'n groter wêreld in aanraking gekom het toe bekende mense op die dorp verskyn het, mense soos Johannes van der Walt, die stoeier, en die atleet Danie Joubert. 'n Mens kan jou ook verwonder oor die skrywer se reaksie op musiek. Ons leef tans in 'n geluidbesoedelde wêreld; daar is nooit 'n tyd en bykans nêrens 'n plek waar daar nie musiek speel nie. Vir Van Niekerk was dit 'n lewensveranderende ervaring toe hy die eerste keer die vierde klavierkonsert van Beethoven oor die radio ('n nuwe beter radio met beter ontvangs) kon hoor en daaruit volg 'n lewenslange passie vir musiek (bl. 117). Kostelik vertel hy hoe G.A. Watermeyer in sy derde jaar op universiteit in hulle koshuis ingetrek het nadat hy die vorige jaar bekroon is vir sy digbundel Sekel en simbaal. Watermeyer het gewoon in die grootste kamer op die eerste verdieping en as 'iemand vermoed dat hy aan gedigte werk, klink dit in die gange op: "Hou julle bekke, Watermeyer dig"' (bl. 150).
Tussendeur kom daar ook herinneringe na vore oor uitsprake van mense wat die leser van vandag weer aan die dink sal sit. So word daar verwys na president Steyn se woorde ná die Anglo-Boereoorlog aan die Engelse: 'Die taal van die veroweraar in die mond van die verowerde is die taal van slawe.' (bl. 78); en Van Wyk Louw se uitspraak in Lojale verset word ook aangehaal: 'Opstand is net so noodsaaklik in 'n volk as getrouheid. Dit is nie eers gevaarlik dat 'n rebellie misluk nie; wat gevaarlik is, is dat ' $\mathrm{n}$ hele geslag sonder protes sal verbygaan' (bl. 70).

Van Niekerk skryf 'n helder, óóp prosa, gemaklik leesbaar en vloeiend. Die eenvoud is egter bedrieglik, want waaroor dit gaan, is 'die mens-wees, ek-wees, hier-wees, gees-wees binne die totaliteit van denke, belewing, intuïsie, spiritualiteit' (bl. 15) in die denke en woorde van 'n goeie skrywer, 'n sensitiewe mens met ' $n$ onfeilbare aanvoeling vir die regte ongekompliseerde woord al gaan dit oor die onbegryplikhede van die lewe.

\section{Literatuurverwysings}

Van Niekerk, D., 2017, Kroniek van turf, Protea Boekhuis, Pretoria.

Van Niekerk, D., 2019, Legkaart van 'n jong lewe: Essays oor wat was en geword het, Protea Boekhuis, Pretoria. 